\title{
Determinants of Information Technology Leadership Program
}

\author{
Roya Anvari ${ }^{1}$, Sobia Irum ${ }^{1}$, Ishak Mad Shah ${ }^{1}$, Negar Mahmoodzadeh ${ }^{1} \&$ Muhammad Ashfaq $^{1}$ \\ ${ }^{1}$ Department of Human Resource Development, Faculty of Management, Universiti Teknologi Malaysia, Skudai, \\ Johor Bahru, Malaysia \\ Correspondence: Roya Anvari, Department of Human Resource Development, Faculty of Management, \\ Universiti Teknologi Malaysia, 81310 Skudai, Johor Bahru, Malaysia. E-mail: roya.anvari@utm.my
}

Received: August 20, 2013 Accepted: March 25, 2014 Online Published: April 14, 2014

doi:10.5539/res.v6n2p45

URL: http://dx.doi.org/10.5539/res.v6n2p45

\begin{abstract}
Information Technology (IT) is an important factor to the success of an organization as it will align and coordinating the organization to their right tracks to achieve the organizational goals. It is essential to maintaining our leadership and success. It is not surprising because IT offers enormous benefits for organizations to grow their leadership skills and societal development. In order to cope with the problems in managing people, it is important to focus on IT leadership program in motivating employees. The current gap on leadership is on evaluation and measurement of the impacts towards the employee's attitude, mainly the organization that are being engaged with. This paper addresses the gap by providing a discussion on IT leadership program on evaluation of employees and information reporting. The evaluation using the leadership approach will not only create a holistic evaluation process, but it will also assist in fostering innovative organization and technology.
\end{abstract}

Keywords: information technology, leadership program, employee's attitude, job satisfaction

\section{Introduction and Background}

It is not new about research on multiple levels of management leadership. The research done on leadership style showed up an analysis where the focus of research was in upper management of studies (34\%), lower-levels of management $(16 \%)$ while middle management only $7 \%$ in the 25 years period prior was found by DeChurch et al. (2010). Previously, leadership style for middle management has been researched less than high and low management. This guides DeChurch and colleagues to presume "the least well empirically-understood phase of organizational leadership happens in the middle level". Luthans and Avolio (2003) emphasized on the importance of includes in future research about authentic leadership where involved of the effects of leaders' positivity on follower's behavior, as well as followers' performance and development. They mentioned that IT leadership program should also focus on the organization performance and the most important is the effectiveness of a leader in leading the organization towards the organization goals. Table 1 shows five key behaviors by organizational leaders and organizational outcomes.

Leadership can also affect the management system as refer to Kotter (2008) by the designing of the organization system. The usage of evidence-based practices in the designing of a program can lead to the job satisfaction that will results in the organization effectiveness. Previous studies have examined the relationship between leadership program and employee's attitudes including organizational commitment and job satisfaction. On the other hand, Hampton et al. (1986), Johnston et al. (1990), and Savery (1991) described that there is no linkage between organizational commitment and leadership program, while Hunt and Liebscher (1973) found a negative association between leaders' production emphasis and some phases of organizational commitment.

By contrast, more recent studies researching charismatic and leadership style have shown, with some keeping, a positive relationship with followers' organizational commitment (Avolio et al., 2004; Barling et al., 1996; Bono \& Judge, 2003). Mutual affect theory reports that certain leadership styles cause subordinate styles, and certain acts of subordinates (for example, low performance) can cause the leader to modify behavior. Several studies support the notion of reciprocal effect between leaders and subordinates. One of the results suggests that leader consideration or employee-centered behavior and leader positive reinforcement both can conduct to employee job satisfaction. Job satisfaction has been illustrated as a major contributor aspect to propose to stay in the international nursing literature (Cavanagh, 1992; Coomber et al., 1997; Strachota et al., 2003), but job satisfaction is a complex phenomenon with many affecting components. 
Table 1. Five key behaviors by organizational leaders

\begin{tabular}{cc}
$\begin{array}{c}\text { Challenging the } \\
\text { processes } \\
\begin{array}{c}\text { Inspiring a shared } \\
\text { vision }\end{array}\end{array}$ & $\begin{array}{c}\text { Transformational leaders search new opportunities in order to transform the } \\
\text { current status. }\end{array}$ \\
$\begin{array}{c}\text { Transformational leaders have an extensive thinking paradigm and have the ability to } \\
\text { imagine the future. }\end{array}$ \\
$\begin{array}{c}\text { Enabling the others to } \\
\text { Modelling the way }\end{array}$ & $\begin{array}{c}\text { Transformational leaders support others in their planning and help to improve } \\
\text { their skills and abilities. }\end{array}$ \\
$\begin{array}{c}\text { Encouraging the hearts } \\
\text { Transformational leaders act clearly about the values and beliefs }\end{array}$ & Transformational leaders would encourage the human workforce to have efforts. \\
\hline
\end{tabular}

It is an attractive issue on style of leadership and the employee's along with organizational effects. Feature approach makes a start of study on IT leadership and become wider from time to time. Via various dimensions, categories of leadership style like supportive, super, entrepreneurial, transactions, participative and servant, it led to emergence of spiritual leaderships.

Amabile et al. (2004), Masadeghrad (2003) and Yukl (2002) stated that to manage an organization, interaction of both leaders and employees who comes from various backgrounds resulting in many leadership style classes. Even though many leadership styles emerged day by day to achieve higher level of performance, it develops best universal definition. Generally, there are two main categories of leadership styles which are leadership style on humanistic-based and on mechanistic-based. Brown (2003), Rad and Yarmohammadian (2006) and Ismail et al, (2010) stated that an active replacement occur in an organization internally and externally to promote leaders in modifying leadership style's paradigms primarily in traditional mechanistic towards humanistic-based for a better achievement of organizational aims and proposition. The traditional leadership style is powerfully influenced by traditional management thoughts and most leaders exploit a mechanism based on leadership style to deal with and manage followers in their organizations (Rad \& Yarmohammadian, 2006; Yousef, 2000). This leadership style is widely exercised in organizations that conduct in a stable market environment, concentrate on internal organizational environments and offer less emphasis to high commitment human resource practices (Coulter \& Robbins, 2008; Ismail et al., 2010; Noe et al., 2007).

The research model of the survey includes 3 leadership styles; instrumental (transactional) as a mechanic-based leadership, supportive and participative leadership that are humanistic-based leadership styles of the study. Job satisfaction for employees is a dimension in providing organization success in particular for human resource management (Snell \& Bohlander, 2010). While Silva (2006) stated that satisfaction of job is an enjoyable sense which emerged in the workplace. This shows the positive effect on employee's job or their condition. Plus, job satisfaction is an employee's affective orientation on their task (Price, 2001).

Several employees can achieve their satisfaction through some factors on their task and may achieve dissatisfaction via some factors (Mullins, 2007). In higher education, private institutions are facing high number of turnover of academic staff (Balakrishnan, 2008). It might be happen due to indirect effect when academic staff feels dissatisfied on the environmental of the task. The correlation of the relationship for academic staff-leaders gives an effect on the satisfaction of job which is proportional to the performance of their job. While Mullins (2007) emphasized the academic organization need's in maintaining high quality of workforce to give customers a better services and outcome. Plus, request on a study about satisfaction level of job in education field use as indicators of feeling and attitude for educators in teaching (Athirah and Muhamad Hasan, 2008). In workplace especially in managing the organization, there must be a problem which maybe rise based on communication, stress, conflict, motivation and leadership. The problems should be managed apparently to prevent decisively affect on its nature and direction of organization. Recruitment is the process by which organization attract potential workers to apply for a job. Locating workers can be through inside and outside of an organization. Recruiting inside workers is carried out by selecting the same worker in the organization. For example, students that had graduated from Universiti Teknologi Malaysia (UTM), can have a chance to be selected as research assistant or a lecturer in UTM. Different from locating outside candidates for a job, it can be done via internet and agencies. By using internet and IT, an organization can recruit employee immediately. The problem is immediate recruitment. This will happen when there are an overload works in a team or an organization, the leader need to find employee immediately in order to ensure that a project or the works can be done in the time that had been set on. Job satisfaction and transformational leadership were being highlighted as important factors for an organization. This study was directed at understanding leadership program among IT leaders in UTM. 
Figure 1 shows the proposed model that will be used to guide the completion of the investigation:

Leadership program Employees' attitudes

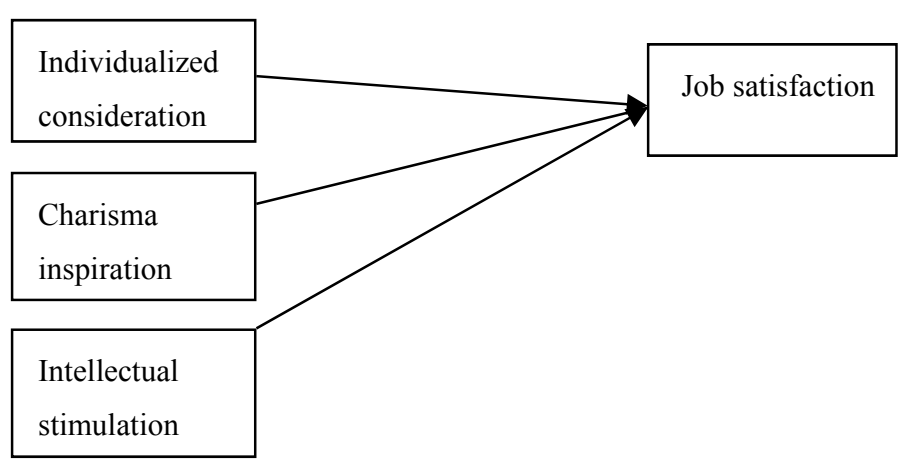

Figure 1. Proposed model of the study

In this theoretical framework, independent variable in this research is leadership style. While, this research has three moderating variables which are individualized consideration, charisma inspiration, and intellectual stimulation. Last but not least, dependent variable in this research is job satisfaction.

This research shows relationship between the variables especially on how leadership style will affect job satisfaction. Various types of leadership style will lead differently on individualized consideration, charisma inspiration and intellectual stimulation. All three of individualized consideration, charisma inspiration and intellectual stimulation will give effect on job satisfaction. Several hypotheses can be developed in this research.

(a) There are various types of leadership style among IT leaders in Universiti Teknologi Malaysia (UTM).

(b) Job satisfaction can be categorized into several levels among the employees.

(c)There is a clear relationship between leadership style and job satisfaction among IT leaders in Universiti Teknologi Malaysia (UTM).

(d) Different style of leadership will affect job satisfaction of employees differently.

\section{Research Methodology}

Through a mixed-method design based on survey of IT leaders as well as interviews with them, the study will combine IT programs on the factors shaping employees attitudes and their causes. Interviews with IT leaders will reflect the influence of determinant of IT programs in job satisfaction. Combining these methods will enable the researcher to generate a huge amount of data which increase the robustness of this study. A subsample of leaders will be interviewed. SPSS package (Version 18) for quantitative data will be used, while the qualitative data will employ the use of Nvivo. The outcomes of the interview sessions will provide evidence regarding type and responsibility to IT leaders in managing people.

\section{Expected Findings}

This study helps researcher to learn and understand the knowledge and information about the relationship between IT leadership program and employee's attitude. This research also determines the kind of leadership styles and the factor to influence job satisfaction and organizational commitment. By doing this research, the researcher can get a lot of valuable experience for seeking the reasons of problems and solving problems. This study help respondents to recognize the relationship between leadership style and job satisfaction, they will get a lot of information and knowledge about leadership style and job satisfaction. Through this research, the respondents can get a new identification for themselves; it is helpful to their job efficiency, job promotion and career development.

\section{Conclusion}

In this paper, the researchers have presented IT leadership as a management function, which is mostly directed towards people and social interaction, as well as the process of influencing people so that they will achieve the goals of the organization. Through an investigation of the leadership styles, it is expected that it is need for 
improving the quality of work-based provision and the need to meet employers' requirements at all levels within the organization.

\section{Acknowledgements}

We would like to extend our appreciation to the Ministry of Higher Education (MOHE, vote number: Q.J130000.2729.00k30) for funding this project and our acknowledgement to the Research Management Center, Universiti Teknologi Malaysia for their support in managing this research.

\section{References}

Amabile, T. M., Schatzel, E. A., Moneta, G. B., \& Kramer, S. J. (2004). Leader Behaviors and the Work Environment for Creativity: Perceived Leader Support. Leadership Quarterly, 15(1), 5-32. http://dx.doi.org /10.1016/j.leaqua.2003.12.003

Athirah \& Muhamad Hasan. (2008). A Content Analysis of Staff Nurse Descriptions of Job Satisfaction and Dissatisfaction. Journal of Advanced Nursing, 29(6), 1332-1341.

Avolio B. J., Zhu, W., Koh, W., \& Bhatia, P. (2004). Transformational Leadership and Organizational Commitment: Mediating Role of Psychological Empowerment and Moderating Role of Structural Distance. Journal of Organizational Behaviour, 25, 951-968. http://dx.doi.org/10.1002/job.283

Balakrishnan, V. (2008). Job Satisfaction, Productivity and Commitment. Journal of Nursing Administration, 25 , $17-26$.

Barling, J., Weber, T., \& Kelloway, E. K. (1996). Effects of Transformational Leadership Training on Attitudinal and Financial Outcomes: A field experiment. Journal of Applied Psychology, 81, 827-832. http://dx.doi.org/10.1037/0021-9010.81.6.827

Bono, J. E., \& Judge, T. A. (2003). Self-Concordance at Work: Toward Understanding the Motivational Effects of Transformational Leaders. Academy of Management Journal, 46, 554-571. http://dx.doi.org/10.2307 /30040649

Brown, B. B. (2003). Employees' Organizational Commitment and Their Perception of Supervisors' Relations-Oriented and Task-Oriented Leadership Behaviors. Virginia Polytechnic Inst. and State Uni.

Cavanagh, P. (1992). Attention-Based Motion Perception. Science, 257, 1563-1565. http://dx.doi.org/10.1126 /science. 1523411

Coomber, B., \& Barriball, K. L. (2007). Impact of Job Satisfaction Components on Intent to Leave and Turnover for Hospital-Based Nurses: A Review of the Research Literature. International Journal of Nursing Studies, 44, 297-314. http://dx.doi.org/10.1016/j.ijnurstu.2006.02.004

Coulter, M., \& Robbins, S. P. (2008). Management. Malaysia: Prentice Hall.

DeChurch, L. A. (2010). Multi-Team Imperatives for Leadership and Organizations. Symposium Presented at the 25th Annual Conference of the Society for Industrial and Organizational Psychology, Atlanta, GA.

Hampton, R., Dubinsky, A. J., \& Skinner, S. J. (1986). A Model of Sales Supervisor Leadership and Retail Sales People's Job-Related Outcomes. Journal of the Academy of Marketing Science, 14, 33-43. http://dx.doi.org /10.1007/BF02723262

Hunt, J. G., \& Liebscher, V. K. C. (1973). Leadership Preference, Leadership Behavior, and Employee Satisfaction. Organizational Behavior and Human Performance, 9, 59-77. http://dx.doi.org/10.1016/0030 $-5073(73) 90037-8$

Ismail A., Zainuddin, N. F. A., \& Ibrahim, Z. (2010). Linking Participative and Consultative Leadership Styles to Organizational Commitment as an Antecedent of Job Satisfaction. Unitar E-Journal, 6(1), 246-253.

Johnston, M. W., Parasuraman, A., Futrill, C. M., \& Black, W. C. (1990). A Longitudinal Assessment of the Impact of Selected Organizational Influences on Salespeople's Organizational Commitment During Early Employment. Journal of Marketing Research, 27(3), 333-334. http://dx.doi.org/10.2307/3172590

Kotter, J. P. (2008). A force for change: how leadership differs from management. Free Press: New York.

Luthans, F., \& Avolio, B. J. (2003). Authentic Leadership: A Positive Developmental Approach. Positive Organizational Scholarship, 241-261.

Masadeghrad, A. M. (2003). The Role of Participative Management (Suggestion System) in Hospital Effectiveness and Efficiency. Research in Medical Sciences, 8(3), 85- 89. 
Mullins, L. (2007). The Relationships among Turnover Intentions, Professional Commitment, and Job Satisfaction of Hospital Nurses. Journal of Professional Nursing, 18(4), 214-219.

Noe, R. A., Hollenbeck, J. R., Gerhart, B. N., Hollenbeck, J. R., Barry, G., \& Wright, P. M. (2007). Human Resource Management: Gaining a Competitive Advantage. New York: McGraw- Hill Companies.

Price, J. L. (2001). Predicting Registered Nurse Job Satisfaction and Intent to Leave. Journal of Nursing Administration, 33(5), 271-283.

Rad, A. M. M., \& Yarmohammadian, M. H. (2006). A Study of Relationship between Managers' Leadership Style and Employees' Job Satisfaction. Leadership in Health Services, 19(2), 11-28. http://dx.doi.org $/ 10.1108 / 13660750610665008$

Savery, L. K. (1991). Perceived and Preferred Styles of Leadership: Influences on Employee Job Satisfaction. Journal of Managerial Psychology, 6(1), 28-33. http://dx.doi.org/10.1108/02683949110140048

Snell, S. A., \& Bohlander, G. W. (2010). Perceived Role Conflict, Role Ambiguity, and Job Satisfaction among Nurse Educators. Journal of Nursing Education, 26, 233-238.

Strachota, E., Normandin, P., O’Brien, N., Clary, M., \& Krukow, B. (2003). Reason Registered Nurses Leave or Change Employment Status. Journal of Nursing Administration, 33(2), 111-117. http://dx.doi.org/10.1097 /00005110-200302000-00008

\section{Copyrights}

Copyright for this article is retained by the author(s), with first publication rights granted to the journal.

This is an open-access article distributed under the terms and conditions of the Creative Commons Attribution license (http://creativecommons.org/licenses/by/3.0/). 